\title{
Heavy metals and macroelements in the tundra of southern Spitsbergen: the effect of little auk Alle alle (L.) colonies
}

\author{
BARBARA GODZIK
}

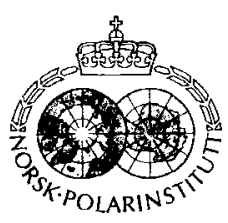

Godzik B.: Heavy metals and macroelements in the tundra of southern Spitsbergen: the effect of little auk Alle alle (L.) colonies. Polar Research 9(2), 121-131.

Samples of two species of widely distributed mosses (Sanionia uncinata and Hylocomium splendens) were collected in the Arickammen-Fugleberget calchment area (Hornsund, Spitsbergen) within and outsidc little auk Alle alle (L.) colonies. The concentrations of $\mathrm{Cd}, \mathrm{Pb}, \mathrm{Ni}, \mathrm{Zn}, \mathrm{Cu}, \mathrm{Mn}$. Fc, $\mathrm{N}, \mathrm{P}$, and $\mathrm{S}$ in the moss samples were found to be 1.5-2 times higher within than outside the colonies. Significant differences were found for $\mathrm{Cd}, \mathrm{Pb}, \mathrm{Zn}, \mathrm{Cu}$, and $\mathrm{Fe}$, but not for $\mathrm{Ni}, \mathrm{Mn}, \mathrm{N}, \mathrm{P}$, and $\mathrm{S}$. Sanionia uncinata accumulates up to $8 \mu \mathrm{g} \mathrm{g}^{-1} \mathrm{~d}$. wt $\mathrm{Cd}, 14-\mathrm{Pb}, 8-\mathrm{Ni}, 47-\mathrm{Zn}, 9-\mathrm{Cu}, 90-\mathrm{Mn}$, and $1920 \mathrm{\mu g} \mathrm{g}^{-1} \mathrm{~d}$. wt Fc, while Hylocomium splendens accumulates up to $4 \mu \mathrm{gg}{ }^{\prime} \mathrm{d}$. wt $\mathrm{Cd}, 12-\mathrm{Pb}, 3-\mathrm{Ni}, 31-\mathrm{Zn}, 5-\mathrm{Cu}, 60-\mathrm{Mn}$, and $840 \mu \mathrm{g} \mathrm{g}^{-1} \mathrm{~d}$. wt Fe . The colonies of seabirds contribute greatly to the supply of elements in the tundra ccosystems of southern Spitsbergen. The effect seems, however, to be limited to rather small areas.

Barbara Godzik, W. Szafer Institute of Botany, Polish Academy of Sciences, Lubicz 46, 31-512 Kraków, Poland.

\section{Introduction}

The Arctic tundra consists mainly of mosses, lichens, and, to a lesser extent, vascular plants. The vegetation cover is compact in a severalkilometre-wide strip along the coast, while the vegetation further inland is more sparse (Billings 1973).

In Arctic regions, the activity of seabirds is one of the main factors that determines the diversity of vegetation and the degree of vegetation cover. In the Hornsund region little auk Alle alle occurs in large numbers while kittiwake Rissa tridactyla, black guillemot Cepphus grille, Brunnich's guillemot Uria lomvia, fulmar Fulmarus glacialis, glaucous gull Larus hyperboreus, and others are less dominating. Large amounts of nutrients are deposited through the faeces of birds. Constituents of the faeces are dissolved by precipitation and thawing waters, transported through tundra systems by temporary streams (Krzyszowska 1983), and partly washed out to sea. The remainder is utilized by the vegetation, which is always more abundant close to sites inhabited by birds than elsewhere (Eurola \& Hakala 1977).

On the coastal cliffs close to the Polish Polar Station at Hornsund there are large colonies of little auks. The little auks feed mainly on Copepods (Calanus sp.) during the summer (Glutz von
Blotzheim \& Bauer 1982; Evans 1981) and on other small marine crustaceans and fish during the autumn (Lydersen et al. 1985, 1988). Marine animals in the Hornsund region contain fairly high concentrations of heavy metals (Protasowicki 1988). According to Godzik (unpubl. data), various species of marine animals (Amphipoda: Gammarellus homari; Decapoda: Eualus gaimardi, Hyas araneus; Echinodermata: Heliometra glacialis; Pisces: Myxocephalus scorpius, Liparis liparis) from the Hornsund area contain about $1.14-6.43 \mu \mathrm{g} \mathrm{g}^{-1} \mathrm{~d}$. wt Cd, 2.2$43.5 \mathrm{~Pb}, 2.5-13.5 \mathrm{Ni}, 49.7-185.3 \mathrm{Zn}, 4.0-45.0 \mathrm{Cu}$, 3.5-22.1 Mn, and 56.8-514.0 $\mathrm{ug} \mathrm{g}^{-1} \mathrm{~d}$. wt Fe. It can be assumed that little auks feeding on these species deposit considerable amounts of the same elements in the tundra ecosystems through their faeces.

Because mosses absorb heavy metal ions, they are often used in the assessment of heavy metal pollution of the environment (Rühling \& Tyler 1978, 1971; Pakarinen \& Tolonen 1976; Grodzińska 1978). By using the common moss species Sanionia uncinata and Hylocomium splendens, this project has aimed at assessing the effect of colonies of little auk on the concentrations of heavy metals, sulphur, nitrogen, and phosphorus in the tundra ecosystem of southern Spitsbergen. 

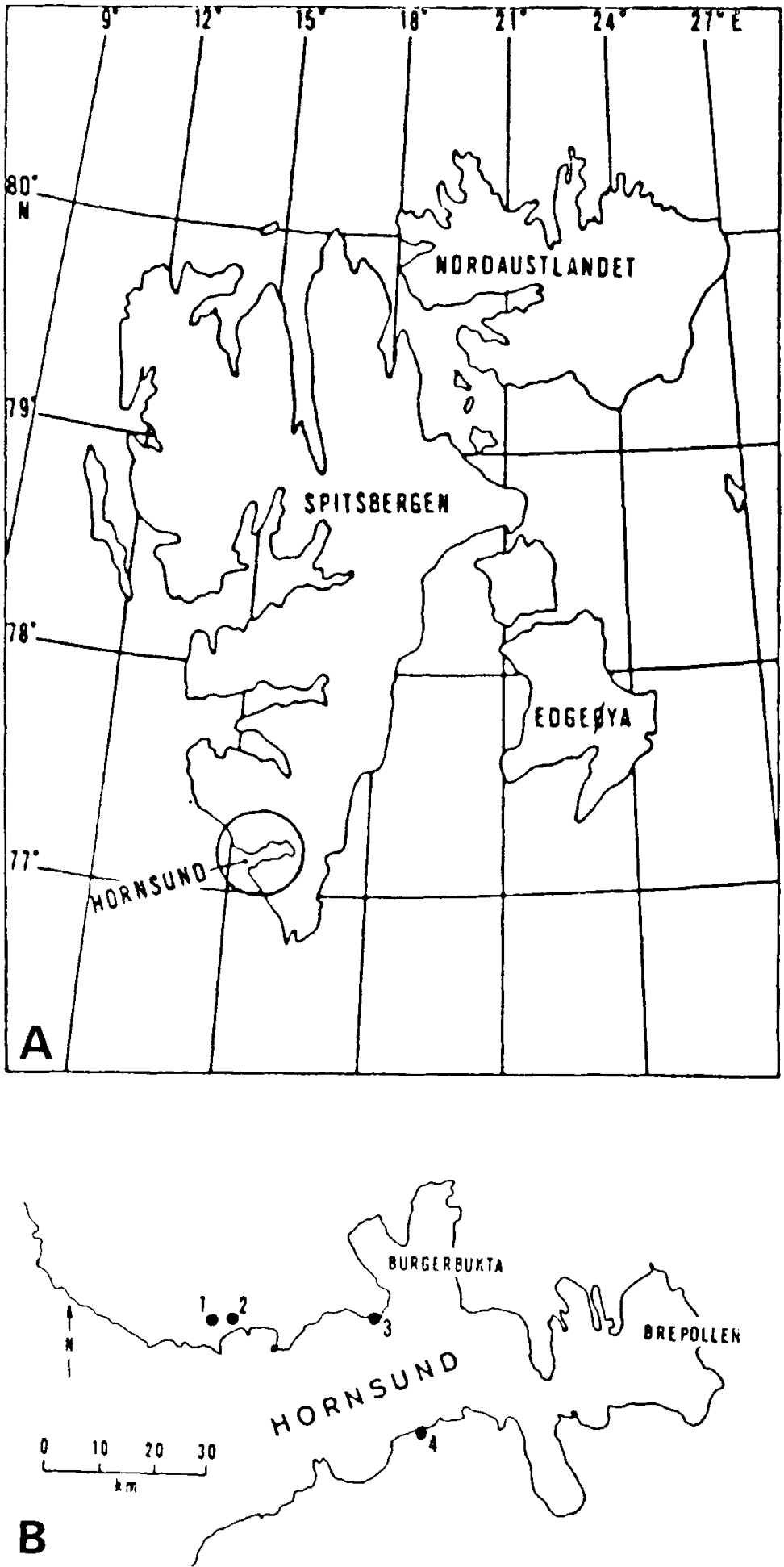

Fig. 1. Location of Hornsund (A) and sites of moss sampling in the Hornsund area (B). $1=$ Ariekammen: $2=$ Fugleberget: $3=$ Gnàlberget: 4 = Rasstupet . 


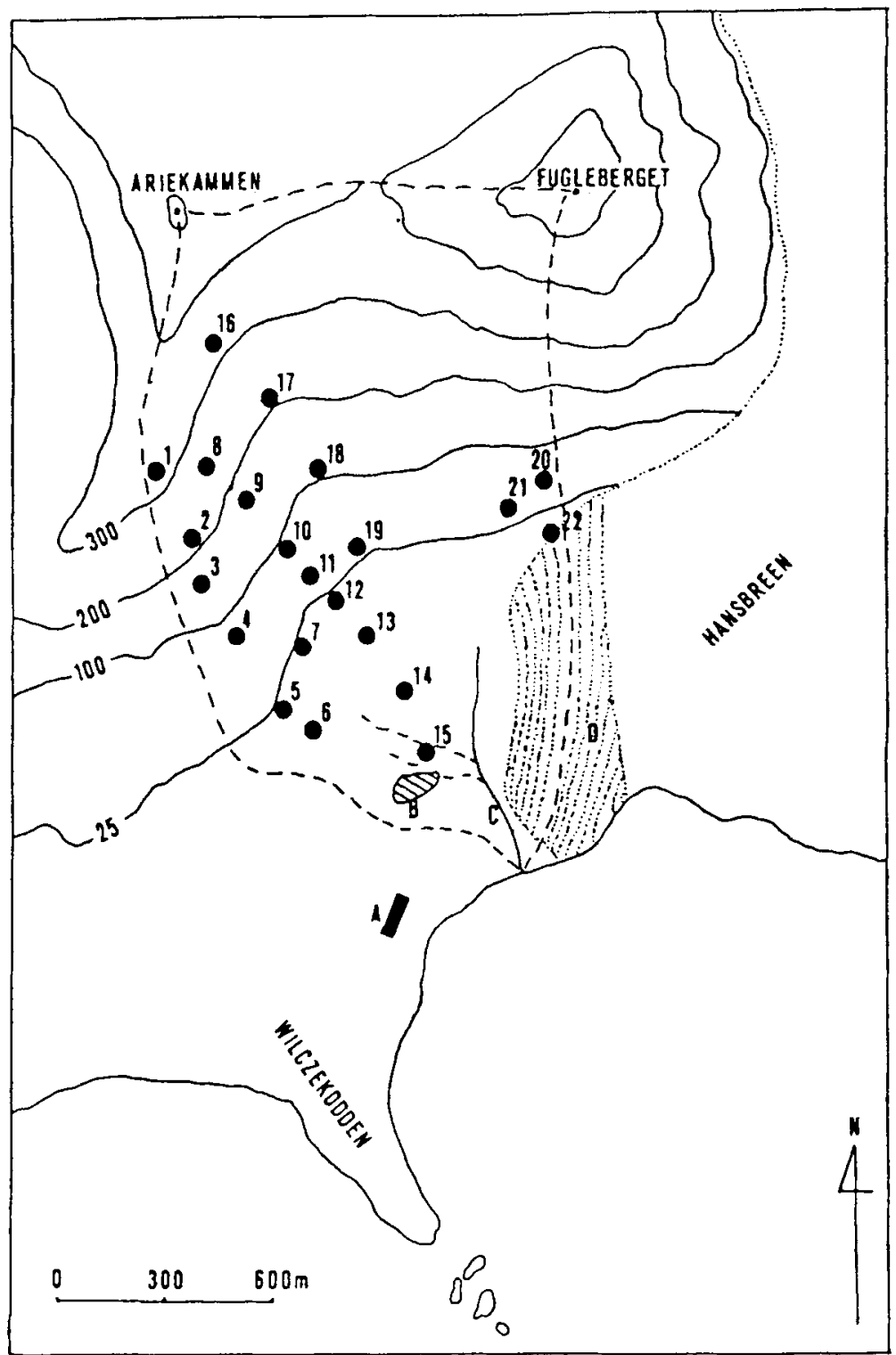

Fig. 2. Sites of moss sampling in Ariekammen-Fugleberget watershed. $A=$ Polish Polar Station: $\mathbf{B}=$ Water pool; $\mathbf{C}=$ Fuglebekken river: $\mathrm{D}=$ Hans Glacier moraine. Broken lines indicate boundarics of the watershed area.

\section{Study area}

The studies were carried out on a fragment of tundra vegetation in the Fuglebekken river catchment area close to the Polish Polar Station at Hornsund in the southwestern part of Spitsbergen $\left(76^{\circ} 59^{\prime} \mathrm{N}, 15^{\circ} 33^{\prime}\right.$ E) (Fig. 1A). The catchment area comprises the southern and southeastern slopes of the Ariekammen (511 m a.s.1.) and Fugleberget $(569 \mathrm{~m}$ a.s.l.) mountains and the flat terrain in the southern part of the catchment (Fig. 2). In the western part of the catchment area. on the slopes of Ariekammen, there is a colony of about 50 thousand pairs of little auks. A mosaic pattern of rock rubble divides the colony into rather autonomic subcolonies. The density of 
breeding pairs is usually one pair per $1.5-2.0 \mathrm{~m}^{2}$ (Stepniewicz 1980). In the eastern part of the catchment area (slopes of Fugleberget) little auks occur less frequently, accompanied by small colonies of kittiwakes. The flat part of the study area is a feeding ground for the pink-footed goose Anser brachyrhynchus.

The vegetation of the Ariekammen-Fugleberget catchment area is variable. The western part (southern slope of Ariekamman) is "fertilized" by birds and supports abundant ornithocoprophilous plant communities, a condition lacking in the eastern part (Dubiel \& Olech in press).

\section{Materials and methods}

Sanionia uncinata (Hedw.) Loeske and Hylcomium splendens (Hedw.) B. S. G. are the most widespread moss species occurring in both the "fertilized" and "nonfertilized" parts of the catchment area. Samples of these mosses were collected in June 1986 within the AriekammenFugleberget catchment area (Fig. 2) and at several other sites in the Hornsund fiord (Fig. 1B; Table
1). Samples were taken in the western part of the catchment area, along three transects leading from points elevated about $300 \mathrm{~m}$ a.s.l. on the slopes of Ariekammen towards the flat coastal terrace about $10 \mathrm{~m}$ a.s.l. (19 samples, locations 1-19), in the eastern part of the catchment area at the foot of Fugleberget ( 3 samples, locations 20-22), close to Gnålberget (1 sample, location 23 ), and on Rasstupet ( 2 samples, locations 2425).

Some of the Sanionia uncinata samples were collected within bird colonies: little auk colonies on Ariekammen (locations 2-4, 9-11, 18), colonies on Fugleberget (location 20-21), within geese-feeding ground (location 14), and within a colony of kittiwake on Rasstupet (location 25). The remaining samples were collected outside bird colonies or feeding grounds.

Five samples of Hylocomium splendens were collected within little auk colonies, on Ariekammen (locations 9-11, 18) and Fugleberget (location 20). The remaining samples were collected either above or below the colonies.

Moss samples were air-dried and then ovendried at $105^{\circ} \mathrm{C}$ to constant weight. The samples were slowly digested in a $4: 1$ mixture of spectral

Table 1 . Number of samples and localitics of moss collection in the Hornsund region $(\mathrm{a}=$ within bird colonies; $\mathrm{b}=$ outside bird colonies)

Species Sanionia uncinata Hylocomium spendens

Locality

\begin{tabular}{|c|c|c|c|}
\hline \multirow{3}{*}{ Ariekammen } & a & $\begin{array}{l}8 \text { samples } \\
\text { locations: } 2.3 .4,9,10,11,14,18\end{array}$ & $\begin{array}{l}4 \text { samples } \\
\text { locations: } 9,10,11,18\end{array}$ \\
\hline & & & \\
\hline & $b$ & $\begin{array}{l}11 \text { samples } \\
\text { locations: } 1,5,6,7,8,12,13,15,16,17,19\end{array}$ & $\begin{array}{l}7 \text { samples } \\
\text { locations: } 1,5,8,12,16,17,19\end{array}$ \\
\hline \multirow[b]{2}{*}{ Fugleberget } & $a$ & $\begin{array}{l}2 \text { samples } \\
\text { locations: } 20.21\end{array}$ & $\begin{array}{l}1 \text { sample } \\
\text { location: } 20\end{array}$ \\
\hline & $\mathrm{b}$ & $\begin{array}{l}\text { I sample } \\
\text { location: } 22\end{array}$ & - \\
\hline \multirow[b]{2}{*}{ Rasstupet } & a & $\begin{array}{l}1 \text { sample } \\
\text { location: } 24\end{array}$ & - \\
\hline & $b$ & $\begin{array}{l}1 \text { sample } \\
\text { location: } 25\end{array}$ & - \\
\hline \multirow{2}{*}{ Gnålodden } & $\mathrm{a}$ & - & - \\
\hline & $\mathrm{b}$ & $\begin{array}{l}1 \text { sample } \\
\text { location: } 23\end{array}$ & - \\
\hline
\end{tabular}


pure nitric and perchloric acids on a hot plate for 3 days until all organic matter was oxidized. The solution was then evaporated to $1 \mathrm{ml}$ and diluted with distilled water to $50 \mathrm{ml}$. Blanks were run for each series of samples. The paper bags in which the plants had been stored were treated in the same way as the moss samples. The concentrations of $\mathrm{Cd}, \mathrm{Pb}, \mathrm{Ni}, \mathrm{Zn}, \mathrm{Cu}, \mathrm{Mn}$, and $\mathrm{Fe}$ were determined with an atomic absorption spectrophotometer (Varian-Techtron model A1000). The measurements were repeated on a Hitachi $180-80$ spectrophotometer. Sulphur was determiend by a nephelometric method, nitrogen by Kjeldahl method, and phosphorus by a vanado-molybdate method (Nowosielski 1968).

The concentrations were determined collec-

Tabie 2. Heavy metal, phosphorus, sulphur $\left(\mu \mathrm{g} \mathrm{g}^{-1} \mathrm{~d} . \mathrm{wt}\right)$, and nitrogen (\%) concentrations in Sanionia uncinata collected in the Hornsund area (localities within bird colonies have been given in frames).

\begin{tabular}{|c|c|c|c|c|c|c|c|c|c|c|c|c|}
\hline \multicolumn{2}{|c|}{ Locality } & No & $\mathrm{Cd}$ & $\mathrm{Pb}$ & $\mathrm{Ni}$ & $Z_{n}$ & $\mathrm{Cu}$ & $\mathrm{Mn}$ & $\mathrm{Fe}$ & $P$ & $S$ & $\mathrm{~N}$ \\
\hline \multirow{7}{*}{\multicolumn{2}{|c|}{ 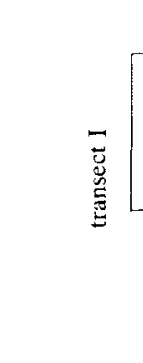 }} & 1 & 1.58 & 6.3 & 1.8 & 18.3 & 3.8 & 25.3 & 407.1 & 1880 & 1206 & 1.16 \\
\hline & & 2 & 3.84 & 10.9 & 1.9 & 31.1 & 5.0 & 35.4 & 428.3 & 2860 & 1729 & 2.09 \\
\hline & & 3 & 6.33 & 12.9 & 2.8 & 42.2 & 6.8 & 37.6 & 575.4 & 2980 & 1895 & 2.37 \\
\hline & & 4 & 7.96 & 12.0 & 2.6 & 46.9 & 8.0 & 34.7 & 530.6 & 3200 & 1856 & 2.34 \\
\hline & & 5 & 3.07 & 4.3 & 1.7 & 17.9 & 2.9 & 48.5 & 509.6 & 1900 & 1297 & 1.31 \\
\hline & & 6 & 1.05 & 5.8 & 2.5 & 13.1 & 2.9 & 29.8 & 122.6 & 1680 & 996 & 0.94 \\
\hline & & 7 & 2.27 & 5.3 & 2.6 & 23.1 & 6.5 & 55.2 & 291.4 & 2800 & 1680 & 1.97 \\
\hline \multirow{12}{*}{ 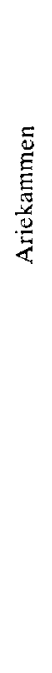 } & \multirow{8}{*}{ 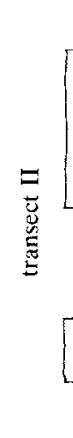 } & 8 & 2.41 & 11.1 & 2.6 & 22.4 & 3.7 & 38.3 & 289.6 & 1700 & 1264 & 0.94 \\
\hline & & 9 & 1.97 & 13.7 & 8.1 & 37.4 & 6.8 & 90.2 & 839.7 & 2390 & 1143 & 1.66 \\
\hline & & 10 & 2.12 & 13.7 & 2.7 & 22.4 & 4.2 & 42.7 & 866.9 & 1670 & 1023 & 1.24 \\
\hline & & 11 & 4.48 & 12.2 & 1.9 & 33.9 & 5.4 & 29.1 & 486.3 & 2880 & 1886 & 2.07 \\
\hline & & 12 & 4.47 & 8.5 & 1.8 & 37.6 & 5.2 & 38.5 & 174.7 & 3240 & 1649 & 2.20 \\
\hline & & 13 & 1.32 & 4.3 & 1.7 & 21.7 & 4.3 & 36.6 & 220.5 & 2630 & 1522 & 1.69 \\
\hline & & 14 & 1.13 & 10.4 & 5.3 & 21.6 & 8.4 & 71.4 & 1354.5 & 2800 & 1361 & 1.59 \\
\hline & & 15 & 0.81 & 11.7 & 4.6 & 13.6 & 3.7 & 41.3 & 1058.4 & 2650 & 1058 & 1.03 \\
\hline & \multirow{4}{*}{$\begin{array}{l}\Xi \\
\Xi \\
\tilde{U} \\
\tilde{E} \\
\Xi\end{array}$} & 16 & 1.82 & 8.8 & 2.2 & 14.2 & 2.6 & 21.5 & 184.3 & 1370 & 1127 & 1.12 \\
\hline & & 17 & 1.64 & 9.0 & 2.7 & 12.9 & 5.0 & 36.5 & 794.7 & 1670 & 1303 & 1.24 \\
\hline & & 18 & 1.66 & 10.8 & 5.6 & 22.0 & 8.7 & 88.0 & 331.4 & 1970 & 1071 & 0.89 \\
\hline & & 19 & 1.56 & 6.3 & 1.7 & 17.3 & 3.8 & 17.0 & 301.4 & 1960 & 1311 & 1.14 \\
\hline \multirow{3}{*}{\multicolumn{2}{|c|}{ Fugleberget }} & 20 & 1.87 & 9.5 & 5.4 & 17.6 & 10.0 & 72.7 & 1362.3 & 2900 & 1262 & 1.87 \\
\hline & & 21 & 1.08 & 9.7 & 6.0 & 18.2 & 8.3 & 106.1 & 1919.7 & 2160 & 1303 & 1.37 \\
\hline & & 22 & 1.56 & 10.6 & 2.6 & 13.1 & 2.8 & 32.8 & 425.5 & 1460 & 1273 & 1.19 \\
\hline Gnå & dden & 23 & 1.25 & 7.4 & 2.6 & 15.1 & 2.9 & 10.7 & 253.0 & 1630 & 1208 & 0.68 \\
\hline \multirow{2}{*}{\multicolumn{2}{|c|}{ Rasstupet }} & 24 & 3.15 & 12.7 & 2.1 & 16.2 & 2.6 & 14.5 & 212.2 & 2320 & 1744 & 1.37 \\
\hline & & 25 & 1.62 & 7.9 & 2.1 & 12.3 & 1.2 & 12.6 & 59.7 & 1570 & 1120 & 0.91 \\
\hline
\end{tabular}


Table 3. Mean concentrations of heavy metals, phosphorus. sulphur ( $\mu \mathrm{g} \mathrm{g}^{-1} \mathrm{~d} . \mathrm{wt}$ ) and nitrogen (\%) in Sanionia uncinata collected within the little auk colony on the slope of Ariekammen (I). outside the little auk colony on the slope of Ariekammen (II), in small bird colonies at the fool of Fugleherget and Rasstupct (III). outside small bird colonies on Fugleberget, Gnålodden and Rasstupet (IV).

\begin{tabular}{|c|c|c|c|c|c|c|c|c|c|c|c|}
\hline Locality & & $\mathrm{Cd}$ & $\mathrm{Pb}$ & $\mathrm{Ni}$ & $\ln$ & $\mathrm{Cu}$ & $\mathrm{Mn}$ & $\mathrm{Fe}$ & $\mathrm{P}$ & $S$ & $\mathrm{~N}$ \\
\hline I & $\bar{x}$ & 4.05 & 12.3 & 3.7 & 33.7 & 6.4 & 51.1 & 579.8 & 2564 & 1515 & 1.81 \\
\hline$(2.3,4,9,10,11)$ & SD & 2.398 & 1.20 & 2.33 & 9.41 & 1.63 & 26.28 & 202.41 & 569.7 & 412.7 & 0.568 \\
\hline I! & $\overrightarrow{\mathrm{s}}$ & 2.190 & 6.2 & 2.4 & 19.3 & 4.0 & 35.1 & +36.8 & 2136 & 1.310 & 1.34 \\
\hline$(1,5,6,7,5.12 .13 .15)$ & $\mathrm{SD}$ & 1.1139 & 3.10 & 0.85 & 4.41 & 1.16 & 11.29 & $4(j 2.70$ & 591,9 & 224.8 & 0.425 \\
\hline III & $\dot{x}$ & 1.81 & 10.58 & 4.7 & 18.4 & 7.3 & 66.2 & 1212.2 & 2545 & 1418 & 1.55 \\
\hline$(20.21,24)$ & $\mathrm{SD}$ & 0.965 & 1.47 & 1.76 & 2.29 & 3.25 & 38.01 & 717.25 & 360.5 & 221.4 & 0.237 \\
\hline IV & $\dot{x}$ & 1.48 & 8.6 & 2.4 & 13.7 & 2.3 & 18.7 & 246.1 & 1553 & 1202 & 0.93 \\
\hline$(22.23 .25)$ & SD & 0.198 & 1.72 & 0.24 & 1.25 & 0.95 & 12.25 & 183.00 & 86.2 & 79.2 & 0.255 \\
\hline
\end{tabular}

tively for the green and brown parts of the mosses. Only three samples of Sanionia uncinata were subjected to separate analysis of the green and brown parts. Differences in heavy metal concentrations were assessed by a Kruskall-Wallis and Student t-test. The heavy metal index $\left(S_{j}\right)$ was calculated according to a procedure suggested by Grodzińska (1978) from the formula

$$
S_{i}=\sum_{i=1}^{l=i} \frac{x_{i j}-\overline{\mathbf{x}}_{i}}{\bar{x}_{i}}
$$

where $x_{11}$ is the content of i-heavy metal in $\mathrm{j}$ location; $\bar{x}_{i}$ - mean content of i-heavy metal in all locations: in this case $\mathrm{j}$ equals 7 ( $\mathrm{Cd}, \mathrm{Pb}, \mathrm{Ni}$. $\mathrm{Zn}, \mathrm{Mn}, \mathrm{Fe}$ ).

\section{Results}

The chemical composition of the samples of Sanionia uncinata collected across the Ariekammen slopes varies considerably (Table 2). Cadmium and manganese show the widest ranges. and lead, copper, sulphur and phosphorus showed the narrowest ranges.

The variation is particularly high in the concentrations of heavy metals and macroelements found along transects $I$ and II; variation along transect III is much smaller. Along transect I. the concentration of cadmium increases sixfold in locations approaching the centre of a colony; that of lead, zinc and nitrogen increases twofold; and the remaining elements increase about 1.5 times. The highest concentrations were found at locations 3.4 and 9 where the nests of birds were most densely arranged. Among locations situated within the colonies, the lowest concentrations of elements were found in moss from location 18 which has few nests of little auks (Table 2).

When samples of the same species of moss were collected on the Ariekammen slopes outside the colonies of little auks (localities 1, 5, 6, 7, 8, 12, $13,15)$, the average concentrations of cadmium, lead and zinc were less than half those found within the colonies, concentrations of copper and manganese were about one-third, and of nickel and iron about one-fourth as much (Table 3).

Samples of the moss $S$. uncinata collected at locations with few birds (localities 20, 21, 24) contained less than half the amount of the concentrations of cadmium and zinc found within colonies on the Ariekammen slopes and similar concentrations of the remaining elements (Table 3 ). Lower concentrations of heavy metals and macroelements were found in the samples of $S$. uncinata collected about 100-300 metres below the small groupings of nests (Table 3 ).

The differences in concentrations of $\mathrm{Cd}, \mathrm{Pb}$, $\mathrm{Zn}, \mathrm{Cu}$, and $\mathrm{Fe}$ in the mosses collected within and outside colonies were statistically significant $(\mathrm{P}<0.05)$.

The total index $\left(S_{j}\right)$ of heavy metal concentrations in the mosses allows the separation of the site locations into low content locations (index values ranging from -0.45 to 0.0 ) and high content locations (index values ranging from 0.0 to $0.64)$. The first group comprises the locations outside the bird colonies; the latter comprises those within the colonies (Fig. 3).

The moss Hylocomium splendens is a weaker heavy metal accumulator than Sanionia uncinata. 


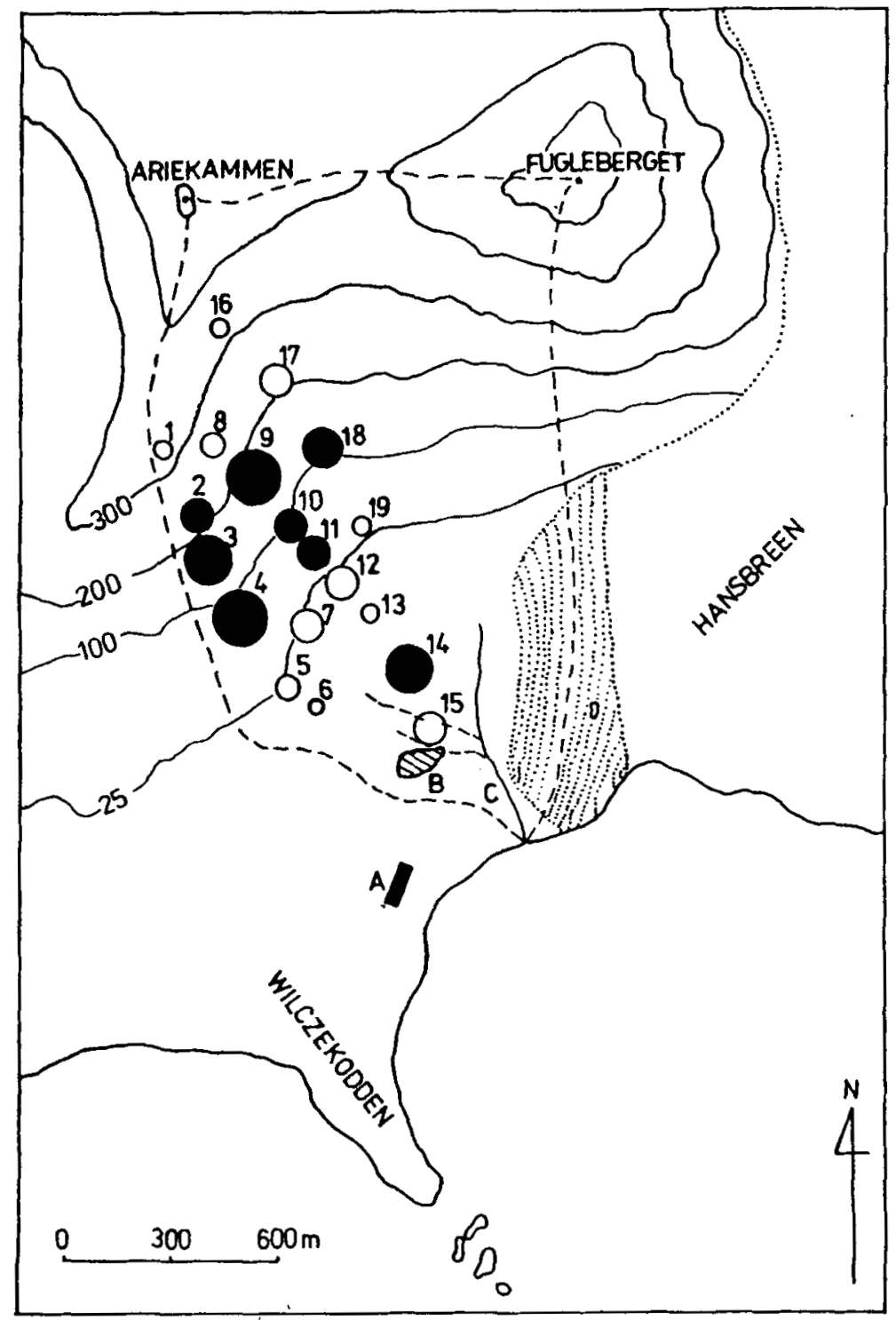

Fig. 3. Index of heavy metal contents of the moss Sanionia uncinata collected on the slope of Mt. Ariekammen. Solid circle (O) $=$ localities within the Alle alle colony (index value: $0.0-0.64)$ and in the feeding ground of Anser brachyrhynchus (locality 14 , index value: 0.44 ). Open circle $(O)=$ localities outside the Alle ale colony (index value: $-0.45-0.0$ ). Other explanations as in Fig. 2 .

$H$. splendens accumulated only about half the amount of $\mathrm{Cd}, \mathrm{Ni}, \mathrm{Zn}$ and $\mathrm{Mn}$, and about twothird the amount of the remaining elements as did $S$. uncinata. Similar to $S$. uncinata, samples of $H$. splendens collected within colonies contained higher heavy metal concentrations than those from outside bird-inhabited sites (Table 4).

The concentrations of heavy metals in the younger, green parts of $S$. uncinata mosses were always lower than those in the older brown parts (Fig. 4). The greatest differences occurred in $\mathrm{Ni}$ and $\mathrm{Mn}$ concentrations. The brown parts contained 3 to 12 times more $\mathrm{Ni}$ and $\mathrm{Mn}$ than the green parts. The concentration of cadmium was 1.5 to 2 times higher, lead 2-3 times, zinc 3-5 times, and copper 3-7 times more than in the green parts (Fig. 4). The differences were statistically significant $(P<0.05)$. Phosphorus and 
Table f. Heary metals, phosphorus. sulphur (ug $\mathrm{g}^{-1} \mathrm{~d}$.wt) and nitrogen $\left(C_{i}\right)$ concentrations of the moss Hylocomium splendens collecled in the Hornund area (localitics within bird colonics hase given in frames).

\begin{tabular}{|c|c|c|c|c|c|c|c|c|c|c|c|}
\hline Lociality & Sis & $\mathrm{Cd}$ & $\mathrm{Ph}$ & $\mathrm{Ni}$ & $\angle n$ & $\mathrm{Cu}$ &. $\ln$ & Fo & $\mathbf{P}$ & $s$ & $\mathbf{N}$ \\
\hline \multirow{11}{*}{ } & 1 & 0.96 & 3.8 & 0.7 & 13.2 & 2.11 & 17.7 & 173.1 & 1591 & 827 & 1.15 \\
\hline & 5 & 11.83 & 3.5 & 1.11 & 13.1 & 2.5 & 21.3 & 204.9 & |6xil & 938 & 1.111 \\
\hline & $s$ & $1 .(k)$ & 12.0 & 1.6 & 11.1 & 2.7 & 16.1 & $3 \times x .7$ & 1720) & 869 & 1.37 \\
\hline & 4 & 1.06 & 8.6 & 1.4 & 12.7 & 3.7 & 13.11 & 14.3 .1 & $15(n)$ & $8(1)$ & 0.94 \\
\hline & 10 & $1 .(n)$ & 11.3 & 2.3 & 10.5 & 3.4 & 16.3 & +7.3 .1 & $13(x)$ & 692 & 0.86 \\
\hline & 11 & 4.23 & 7.11 & 1.7 & 31.5 & 4.4 & 28.4 & 316.2 & $28(x)$ & 16.30 & 1.92 \\
\hline & 12 & 11.45 & 5.2 & 11.5 & 111.4 & 2.3 & 111.4 & 259.2 & $13+11$ & 615.5 & 0.81 \\
\hline & in & 1.411 & $n .1$ & 11.9 & 4.9 & 2.2 & 11.5 & 345.1 & 1630 & 1149 & 1.115 \\
\hline & $1^{-}$ & 1.111 & $6 . x$ & 2.2 & 10.11 & 2.8 & 32.4 & 562.1 & $129(1)$ & $10 \times 7$ & 0.67 \\
\hline & is & 1.311 & 7.5 & $2 . x$ & 1s.s & +.1 & 57.6 & $8+11.2$ & 13811 & sil & (1. 6 (1) \\
\hline & 14 & 11.9 .3 & 5.9 & 1.7 & 11.5 & t.h & 13.4 & 142.1 & $1+20$ & 929 & 10.69 \\
\hline burd cislon! & $\begin{array}{l}\bar{x} \\
\mathrm{~S}(1)\end{array}$ & $\begin{array}{l}1.42 \\
1.5+4\end{array}$ & $\begin{array}{l}8.6 \\
1.92\end{array}$ & $\begin{array}{l}2.2 \\
11 .+4\end{array}$ & $\begin{array}{l}16.4 \\
9.43\end{array}$ & $\begin{array}{l}+.11 \\
11.311\end{array}$ & $\begin{array}{l}28.5 .3 \\
20.29\end{array}$ & $\begin{array}{l}455.6 \\
2811.44\end{array}$ & $\begin{array}{l}1760 \\
7.37 .9\end{array}$ & $\begin{array}{l}1(x) x \\
42 x .5\end{array}$ & $\begin{array}{l}1.108 \\
0.58\end{array}$ \\
\hline $\begin{array}{l}\text { cutsidc } \\
\text { bird colson! }\end{array}$ & $\begin{array}{l}\bar{x} \\
S D\end{array}$ & $\begin{array}{l}1 .(10) 2 \\
11.184\end{array}$ & $\begin{array}{l}6.2 \\
2.63\end{array}$ & $\begin{array}{l}1.3 \\
0.62\end{array}$ & $\begin{array}{l}11.3 \\
1.35\end{array}$ & $\begin{array}{l}2.7 \\
0 . x 7\end{array}$ & $\begin{array}{c}17.5 \\
7.55\end{array}$ & $\begin{array}{l}282.2 \\
1+6.6 x\end{array}$ & $\begin{array}{l}1524 \\
172.1\end{array}$ & $\begin{array}{l}\text { (x)1 } \\
159.7\end{array}$ & $\begin{array}{l}10.96 \\
1.256\end{array}$ \\
\hline Fugkterget & 31 & 1.74 & 5.11 & 2.2 & 12.6 & 3.4 & 11.7 & 664.6 & $2(1+1)$ & 1173 & 1.118 \\
\hline
\end{tabular}

sulphur were accumulated most efficiently in the brown parts. while nitrogen in the green parts (Fig. +).

\section{Discussion}

The group nesting of seabirds in the Far North regions is a major factor in influencing the variability and abundance of plant associations. In the sites fertilized by bird faeces, specific ornithocoprophilous associations have developed (Eurola \& Hakala 1977: Dubiel \& Olech in press).

The presence of a great colony (comprising more than 50 thousand pairs) of little auks on the slope of the Ariekammen mountains has caused vegetation to thrive much better than elsewhere in the catchment area.

The little auks remain in their breeding colonies from mid-June to mid-August before later migrating south. In this period. egg-laying. incubation. and feeding of the young take place. Adult and young birds consume about 280 metric tonnes of marine food during this period. About a third of this amount is voided as faeces deposited mainly within the colonies (Klekowski \& Opaliński 1984).

Previous studies have shown that the concentrations of nitrogen (as nitrates) and phosphorus in surface waters were high within the colonies but decreased with increasing distance from the colonies (Krzyszowska 1985).

Similarly, the concentrations of $N, P$ and $S$ in mosses collected within little auk colonies at Hornsund were higher than those found in mosses growing on sites not inhabited by birds. This indicates the effect bird colonies have on the levels of macroelements in tundra vegetation of the region. Such elevations of macroelement concentrations were also found in higher plants of Spitsbergen by Staaland et al. (1983).

The range of colony-related effect is small. The concentrations of heavy metals in mosses collected less than $100 \mathrm{~m}$ from bird nests are simi- 


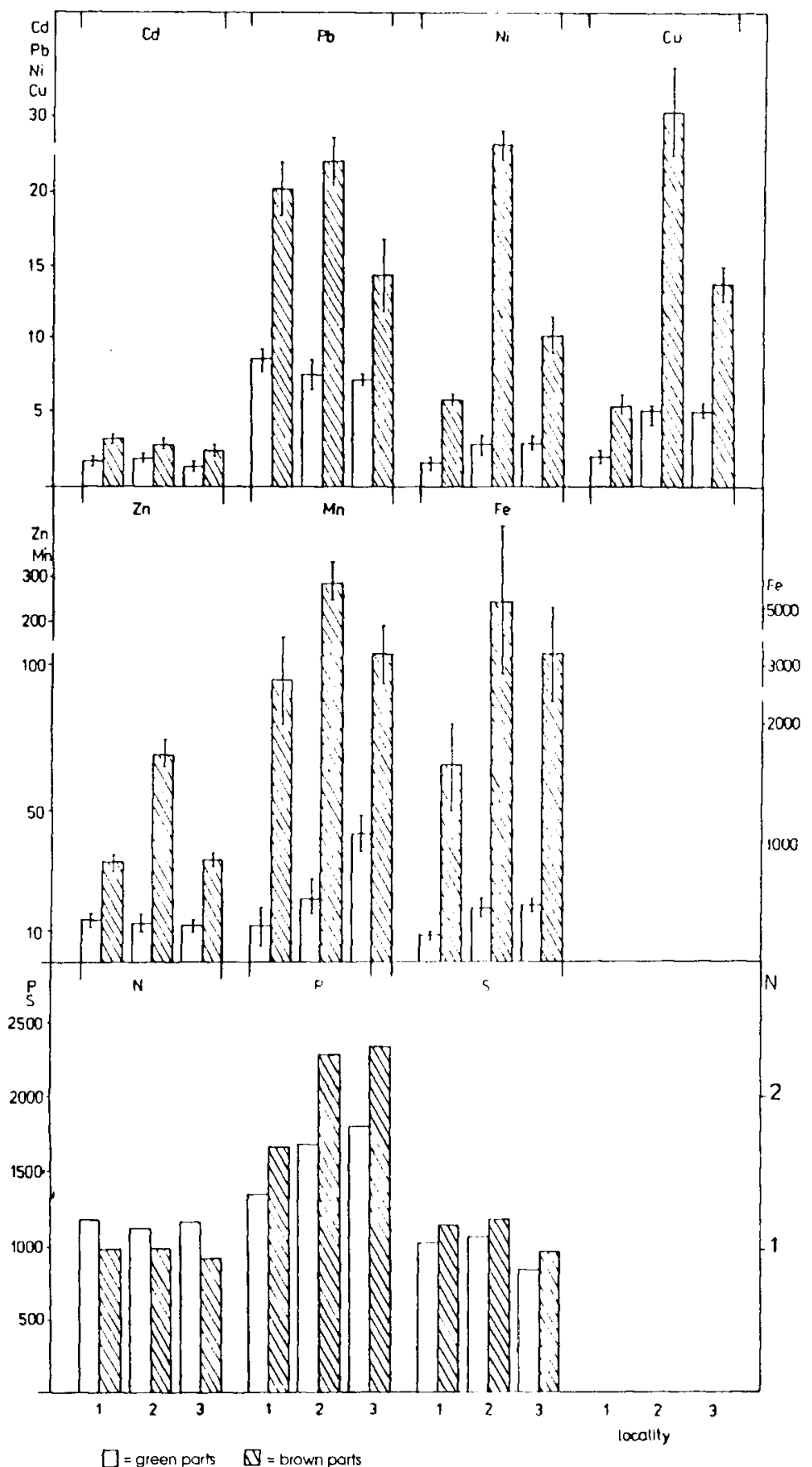

Fig. 4. Heavy metal, phosphorus. sulphur ( $\mu \mathrm{g} \mathrm{g}^{-1} \mathrm{~d}$. wt) and nitrogen (\%) concentrations in grcen and brown parts of the moss Sanionia uncinata (localities 1,2, and 3, southern slope of Mt. Ariekammen). 
Table 5. Heavy metal. phosphorus. sulphur $\left(\mu \mathrm{g}^{-1} \mathrm{~d}\right.$. wi) and nitrogen $(\%)$ concentrations in the green (a) and brown (b) parts of the moss Sanionia uncinatu (localities 1.2. and 3 on the southern slope of Mt. Ariekammen).

\begin{tabular}{|c|c|c|c|c|c|c|c|c|c|c|c|c|}
\hline \multirow{2}{*}{$\frac{\text { Locality }}{\text { Element }}$} & \multicolumn{4}{|c|}{1} & \multicolumn{4}{|c|}{2} & \multicolumn{4}{|c|}{3} \\
\hline & a & SD & $b$ & SD & $\mathrm{a}$ & SD & b & $\mathrm{SD}$ & a & SD & $\mathrm{b}$ & SD \\
\hline $\mathrm{Cd}$ & 1.74 & 0.104 & 3.21 & 0.226 & 1.90 & 0.223 & 2.75 & 0.193 & 1.34 & 0.166 & 2.43 & 0.221 \\
\hline $\mathrm{Pb}$ & 8.6 & 1.00 & 20.2 & 1.87 & 7.50 & 1.21 & 22.6 & 1.70 & 7.2 & 0.29 & 15.3 & 2.45 \\
\hline $\mathrm{Ni}$ & 1.5 & 0.10 & 58 & 0.59 & 2.5 & 0.57 & 23.2 & 0.92 & 2.9 & 0.42 & 10.3 & 1.32 \\
\hline $\mathrm{Zn}$ & 13.9 & 2.31 & 34.1 & 2.69 & 13.2 & 3.20 & 68.8 & 5.55 & 12.5 & 1.67 & 34.6 & 3.76 \\
\hline $\mathrm{Cu}$ & 2.1 & 0.29 & 5.4 & 0.75 & 5.2 & 0.96 & 28.1 & 3.50 & 5.0 & 0.29 & 13.8 & 1.42 \\
\hline $\mathrm{Mn}$ & $12.1)$ & 2.42 & 95.3 & 6.01 & 21.1 & 2.30 & 298.4 & 20.48 & 43.3 & 3.70 & 116.3 & 8.14 \\
\hline $\mathrm{Fe}$ & 239.2 & 15.70 & 1661.3 & 261.68 & 451.1 & 62.83 & 5184.7 & 499.81 & 474.7 & 41.68 & 3218.7 & 375.43 \\
\hline $\mathrm{p}$ & 1340 & - & 1650 & - & 1690 & - & 2290 & - & 1810 & - & 2333 & - \\
\hline 5 & 1035 & - & 1143 & - & 1204 & - & 1059 & - & 949 & - & 834 & - \\
\hline $\mathrm{N}$ & 1.19 & - & 0.97 & - & 1.12 & - & 0.97 & - & 1.18 & - & 0.91 & - \\
\hline
\end{tabular}

lar to (except for cadmium) the levels found elsewhere in Hornsund. According to data by Grodzińska \& Godzik (1991, this volume), mean concentrations of heavy metals in Sanionia uncinata from many locations in Hornsund area are $\left(\mu \mathrm{g} \mathrm{g}^{-1}\right)$ : $\mathrm{Cd}, 0.59 ; \mathrm{Pb}, 7.07 ; \mathrm{Ni}, 4.25 ; \mathrm{Cu}, 6.01$; and $\mathrm{Zn}, 21.13$. Hylocomium splendens accumulates similar quantities of these elements. Since concentrations of cadmium, lead and zinc in Sanionia uncinata and Hylocomium splendens collected within bird colonies are considerably higher than the levels found on many locations elsewhere in southern Spitsbergen, the faeces of sea birds is an important source of heavy metals in sites inhabited by birds.

Higher concentrations of heavy metals found in older (brown) parts of mosses compared with younger (green) parts agree well with findings by other authors (Lötschert et al. 1975; Grodzińska 1978).

It may thus be concluded that colonies of seabirds play an important role in introducing heavy metals and macroelements to the tundra ecosystems of southern Spitsbergen. The range of this effect is limited to the closest sur roundings of colonies of nests.

Acknowledgements. - This work was supported by the Polish Academy of Sciences. programme CPBP 03.03.

\section{References}

Billings, W. D. 1973: Arctic and alpine vegetations: similarities. differences and susceptibility to disturbance. Bioscience 23 . $697-704$
Dubiel, E. \& Otech, M. (in press): Ornithocoprophilous plant communities on the southern slopes of Ariekammen (Hornsund region, Spitsbergen). In Opaliński, K. W. \& Klekowski, R. Z. (eds.): Spitsbergen '84: Landscape, life, w'orld and man in High Arctic. Institute of Ecology publishing, Ossolineum, Wrocław, 1992.

Eurola. S. \& Hakala, U. K. 1977: The bird cliff vegetation of Svalbard. Aquilo, Ser Bot. 15, 1-18.

Evans, P. G. H. 1981: Ecology and behavior of the little auk Alle alle in west Greenland. Ibis 123, 1-18.

Glutz von Blotzheim. U. N. \& Bauer, K. 1982. Handbuch der Vogel Mitteleuropas. Akademische Verlagsgesellschaft, Wicsbaden. 8/II, 1209-1228.

Grodzińska. K. 1978: Mosses as bioindicators of heavy metals pollution in Polish National Parks. Water, Air, Soil Pollut. 9 , 83-97.

Grodzińska, K. \& Godzik, B. 1991: Heavy metals and sulphur in mosses from southern Spitsbergen. Polar Research $9_{(2)}$. 133-140.

Klekowski, R. Z. \& Opaliński. K. W. 1984: Matter and energy flow in Spitsbergen tundra. Wiad. Ekol. 30, 143-166.

Krzyszowska, A. J. 1983: Wlasności chemiczne wód powierzchniowych i ścieków na wybrzeżu zatoki Isbjørnhamna (fiord Hornsund, Spitsbergen). Pp. 102-103 in XII Zjazd Hydrobiologów Polskich w Lublinie. Referaty plenarne i streszczenia komunikatów. Lublin.

Krzyszowska, A. J. 1985: Chemistry of the Fugleberget drainage basin. Pol. Polar Res. 6(3), 341-347.

Lötschert. W.. Wandtner, R. \& Hiller, H. 1975: Schwermetallanreicherung bei Bodenmossen in Imissionsgebiten. Ber. Deutsch. Bot. Ges. 88, 419-431.

Lydersen, Ch., Gjertz, I. \& Węsławski, J. M. 1985: Aspects of vertebrate feeding in the marine ecosystem in Hornsund, Svalbard. Norsk Polarinstitutt Rapportserie $21.57 \mathrm{pp}$.

Lydersen, Ch., Gjetz. I. \& Węslawski. J. M. 1988: Stomach contents of autumn-feeding marine vertebrates from Hornsund, Svalbard. Polar Record 25, 107-114.

Nowosielski. O. 1968: Metody oznaczania potrzeb nawozenia. PWRiL. Warszawa. $688 \mathrm{pp}$.

Pakarinen, P. \& Tolonen. K. 1976: Regional survey of heavy metals in peat mosses (Sphagnum). Ambio 5, 38-40.

Protasowicki. M. 1988: Wstępne badania zawartości $\mathrm{Hg}, \mathrm{Cd}$, $\mathrm{Pb}, \mathrm{Cu}$ i $\mathrm{Zn}$ w golcu (Salvelinus alpinus L.) i innych organizmach $z$ rejonu Hornsundu. Pp. 375-379 in: Jahn. A., 
Pereyma, J. \& Szczepankiewicz-Szmyrka (eds.): XV Sympozjum Polarne. Stan obecny i wybrane problemy polskich badań polarnych. Wydawnictwa Uniwersytetu Wroclawskiego, Wroclaw.

Rühling, A. \& Tyler, G. 1968: An ecological approach to the deposition of heavy metals over Scandinavia. Bot. Notiser $121,321-342$.

Rühling, A. \& Tyler. G. 1971: Regional differences in the deposition of heavy metals over Scandinavia. J. Appl. Ecol. 8, 497-507.

Staaland, H., Brattback, J., Ekern, K. \& Kildemo, K. 1983 Chemical composition of reindeer forage plants in Svalbard and Norway. Holarctic Ecology 6, 109-122.

Stępniewicz, L. 1980: Breeding biology of Little Auk Plautus alle in the Hornsund region, Spitsbergen. Acta Orn. 18, 126. 
